\title{
OBITUARIES
}

\section{Mr. R. P. Howgrave-Graham}

By the death on March 25 in his seventy-ninth year of Robert Pickersgill Howgrave-Graham, a remarkable life devoted to such varied subjects as electrical science, horology and archæology was brought to its close.

Howgrave-Graham was born in Hampstead into a cultured family. His father was the furst secretary of the Institute, now the Chartered Institute, of Patent Agents.

During 1896-99 Howgrave-Graham studied electrical engineering at Finsbury Technical College under Silvanus Thompson, whom he revered throughout his life as his teacher and his friend. Appointed a demonstrator upon the completion of his course, Howgrave-Graham began to assist Silvanus Thompson in his researches, to undertake teaching duties, and to experiment with Herzian waves and high-frequency electric currents. He showed himself to be an exceptionally lucid, sympathetic and enthusiastic teacher and an experimentalist of high ability.

In the years prior to the First World War, Howgrave-Graham was associated with Lodge and Muirhead in the perfection of the wheel coherer, and he devised during the same period a reed, or forkmaintained, phonic motor of relatively high power. During the War, Howgrave-Graham, who was not physically fit for active service, continued his teaching at Finsbury and engaged in various research projects for the Fighting Services. The sudden death in 1916 of Silvanus Thompson left him to carry on, practically single-handed, the teaching of physics and electrical engineering at Finsbury.

In 1919, Howgrave-Graham left the Finsbury Technical College and took up a similar lectureship at the Northampton Polytechnic, where he continued his teaching work until his retirement in 1945.

Within a few months of the end of the First World War, Howgrave-Graham became engaged in the important patent action resulting from the application of Fleming and the Marconi Company for an extension of the term of Fleming's main thermionic diode patent of 1904. He gave evidence in support of the De Forest Company.

Although a teacher of distinction and a contributor to the early development of wireless telegraphy, Howgrave-Graham's best-known work is not in the field of electrical engineering but in that of archæology. He became an acknowledged expert on medieval machinery and in particular on church clocks. His two greatest works in this field were his researches associated with the restoration of the Wells elock, now in the Science Museum, and the Salisbury clock, which was reinstated in the Cathedral in 1956. Howgrave-Graham's patient and accurate historical research on these elocks, which not only contributed notably to their restoration but also incidentaliy established their dates at 1392 and 1386 , respectively, was a work of real scholarship.

Photography was, for him, handmaiden to archæology. The art of photographing the interesting and beautiful features of the architecture of medieval buildings was one at which he excelled and many of his photographs, some of striking beauty, have been reproduced in books on Gothic art.

Happily for him, retirement from teaching presented a unique opportunity to devote himself singlemindedly to his archæology. $\mathrm{He}$ was appointed as assistant keeper of the muniments at Westminster Abbey. There he earried out much skilful restoration work, including the reinstatement and preservation of the earlier funeral effigies which had suffered severe damage by water during an incendiary bomb attack. His work on the effigies of Edward III and Henry VII revealed that the features of these effigies were actual death masks.

Quiet, kindly and sensitive, Howgrave-Graham was endowed with courage and perseverance and above all with the spirit of inquiry. There was, however, something more which made him the delightful and lovable character which he was. He enjoyed sharing his discoveries, he had a keen sense of humour and he never took himself too seriously. Howgrave-Graham's sense of humour was part and parcel of his feeling for the quaint and the incongruous. Perhaps that is why he was so much in tune with the tonches of humour of the medieval illuminator or stone mason.

Howgrave-Graham married in 1944 Miss Beatrice Purdy, who survives him. J. GreIG

\section{Dr. W. A. Hargreaves}

Dr. William Arthur Hargreaves died at Adelaide on March 31 in his ninety-third year. After an outstanding scholastic career in the University of Melbourne, where he took degrees in arts, science and civil engineering, Hargreaves occupied a number of teaching positions in Victoria and Queensland between 1889 and 1916, when he was appointed director of the Department of Chemistry and Government Analyst for South Australia, a position he occupied until his retirement in 1932 .

Although Hargreaves was an outstanding analyst and a capable research worker (he was awarded the D.Sc. of the University of Adelaide in 1916) his greatest contributions to chemistry in Australia arose out of his interest in the teaching of the subject and the part he played in the formation of societies for the promotion of the profession. He was a member of the Faculty of Science of the University of Adelaide for thirty-one years and served also on the Australian National Research Council and the Council of the South Australian School of Mines. Ho was an executive officer of the Society of Chemical Industry of South Australia throughout its short life (191519) and a foundation member of the Royal Australian Chemical Institute, of which he was president during 1919-21.

Outside his profession, Hargreaves's greatest interest was in motoring; he was the first person in Australia to obtain a driving licence and the first to register a motor-car in South Australia, holding the number plate S.A.1 from 1906 until 1955 . In 1894 , he married Camilla Maud Nicholls, of Melbourne, by whom he had a daughter. Both his wife and daughter predeceased him. HAROLD J. RONDA 